\title{
BLOOD FLOW RESTRICTION IN STRENGTH TRAINING (REVIEW)
}

\author{
Ömür Gülfirat ${ }^{1 \mathrm{i}}$, \\ Halil Bişgin ${ }^{2}$ \\ ${ }^{1}$ Kütahya Dumlupınar University, \\ Graduate Education Institute, \\ Department of Physical Education and Sports \\ Turkey \\ ${ }^{2}$ Kütahya Dumlupinar University, \\ Physical Education and Sports High School, \\ Turkey
}

\begin{abstract}
:
Background/Objective: The aim of this review is to investigate general information about blood flow restriction in strength training. Methods: In this study, the related literature was studied by using the screening model. Data were obtained from various articles and internet websites. Of the indexes and databases used in the research; (6) scientific studies on Yöktez, (3) on Pubmed, (3) on Researchgate, (2) on Physiopedia and (4) on Google Scholar were examined. Scientific studies where the effects of blood flow restriction on sedentary individuals (11), the effects of blood flow restriction on individual athletes (1), the effects of blood flow restriction on team athletes (3), and the effects of blood flow restriction on individuals after injury examined (3), were used in our research. Conclusion: The aim of this review is to investigate the application methods and effects of venous blood flow restriction technique, which has recently become popular in resistance training. In this direction, resistance training applied with the BFR technique has been examined with this review by making a literature review. As a result, it is thought that the BFR technique may have a positive effect on the post-injury recovery process and can also help increase the sportive performance and competition gain. It can be said that it can give positive results in terms of hypertrophy if it is evaluated as an aid to strength training, which is quite popular. It is estimated that they will be able to do their daily activities more freely if it is applied to elderly people. It is thought that a very popular movement such as squat, when applied together with venous blood flow restriction, can increase the strength of jumping, besides, if it is applied in anaerobicbased branches, sportive performance can also increase positively.
\end{abstract}

i Correspondence: email ogulfirat@gelisim.edu.tr 
Keywords: blood flow restriction, occlusion, ischemia, strength training

\section{Introduction}

It is known that high load resistance training is the most successful tool in improving muscle strength and achieving muscle hypertrophy. However, high-load or highintensity exercises are said to be unsuitable in some populations that need muscle strengthening, such as chronic pain patients or post-operative patients, the elderly, and individuals with no sports background. For this, the blood flow restriction (BFR) training method was developed by the Japanese physiotherapist Yoshiaki Sato in the 1960s. This training method is based on creating an occlusion at the return of venous blood flow with the help of a tourniquet while exercising with low weights (Korkmaz, 2018). As a result of the studies conducted in the literature, it is seen that the exercises performed with low intensity in healthy individuals, athletes, the elderly and in the rehabilitation process of disability return with blood flow restriction have positive effects on individuals' muscle strength, muscle hypertrophy and functional parameters.

Strength training is an essential component in many sports and is also an indispensable component of post-sports injury rehabilitation programs. There are various training methods used to increase muscle strength and the effectiveness of most of them has been proven (Wernbom, Augustsson, \& Thomee, 2006).

In the guidelines of the American College of Sports Medicine (ACSM), it is known that exercise performed at an intensity of at least $70 \%$ of 1 repetition maximum (1RM) is effective to create muscle strength and muscle hypertrophy (Kraemer et al., 2002). Exercises performed below this intensity, rarely create muscle strength and muscle hypertrophy. This is because during the resistance exercise, motor units are fired, respectively, according to their structures (Kenney, Wilmore, \& Costill, 2015).

Today, based on these findings, it is known that individuals / athletes have started to use current training methods in different ways while exercising. It is said that one of these current methods is the blood flow restriction (BFR) method used during resistance training for the development of muscle strength / hypertrophy. The reason why this new method is preferred is that blood flow restriction (BFR) training is performed with low intensities, allowing the individual / athlete to develop strength and lead a healthy life without exposing the individual / athlete to intense stress. In addition, it is preferred that it is a low intensity method that can be applied by the elderly and during the rehabilitation process after surgery or disability. (Nakajima et al., 2006).

Fry et al. (2010) stated in their study that the BFR technique showed a 56\% increase in protein synthesis. In another study, Takarada et al. (2000) observed that a low-intensity resistance exercise with moderate vascular occlusion causes significant muscle hypertrophy, such as a high-intensity resistance exercise. In a different study, short and long term effects of various combinations of low-intensity exercise and vascular occlusion were researched, and an increase of $10.3 \%$ in muscle strength and cross-sectional area of knee extensor muscles was detected. In their study, Yokokawa et al. (2008) observed that physical function and muscle strength improved in the experimental group after 8 weeks 
of exercise, which may be associated with exercise-induced growth hormone secretion. In a study conducted after the anterior cruciate ligament reconstruction related to the rehabilitation process, the effect of plyometric training with blood flow restriction on muscle strength, volume and function was investigated and an increase in muscle strength and muscle volume was observed in the measurements performed after 8 weeks of exercise (Jessee, 2018). In a recent study, the effects of squatting with BFR on jump performance were investigated on 12 semi-professional athletes. After the application of BFR, it was found that the jump height after squatting with high intensity BFR was statistically higher than the jump height after low intensity and moderate BFR. $(\mathrm{P}<0.05)$ (Türkdoğan, 2019). In a study he conducted on taekwondo athletes, Boyanmış (2018) examined the effect of plyometric and BFR training on strength development. As a result of muscle strength measurements, a significant difference was found in the group training with BFR compared to the plyometric and control groups $(\mathrm{P}<0.05)$.

\section{Blood Flow Restriction Training}

The blood flow restriction technique is an exercise method that partially restricts arterial access and completely restricts venous outflow in working muscles during resistance exercises (Scott et al., 2015). In other words, the blood flow restriction (BFR) technique involves applying an external pressure to the closest area of the upper and /or lower extremities using a pneumatic tourniquet cuff. When the cuff is inflated, gradual mechanical compression of the vasculature under the cuff occurs and it results in partial restriction of arterial blood flow to structures distal to the center of the body, but more seriously affects venous outflow from the bottom of the cuff in blocking venous return. The compression of the vasculature in the skeletal muscle results in insufficient oxygen supply within the muscle tissue (Larkin et al., 2012).

Blood flow restriction (BFR) training is a safe low-intensity resistance exercise that demonstrates improved muscle growth, muscle strength, oxygen delivery and utilization (VO2Max). There are two methods of practical blood flow restriction (PBFR) and air pressure controlled blood flow restriction (BFR). Both methods are used by wrapping or systematically compressing a working limb to restrict the clearance of blood flow from a working muscle during periods of rest. The restriction and accumulation subsequently of metabolic muscle products results in increased activation of specific muscle growth.

According to the size principle of neuromotor control, type I fibers are fired first in a muscle during low-intensity activity under normal conditions. As the density increases, type II fibers are fired as needed. According to this principle, fast strained muscle fibers can only be fired with high intensity exercises. However, it has been shown that there is an increase in the number of fired type II fibers due to the insufficient oxygen supply for type I muscle fibers and the high metabolite accumulation during lowintensity blood flow restriction exercises. As a result, type II fibers can be fired under ischemic conditions, even if the density is low (Takarada et al., 2000a). 


\subsection{Blood Flow Restriction Mechanism and Application}

When blood flow restriction is applied, as can be seen in Figure 2.1, there is a pressure on the blood vessels and metabolites in the muscle show accumulation. The restriction of the arterial vessel prevents sufficient metabolites such as oxygen and ATP to be transported into the muscle, and the restriction of the return of the venous blood vessel causes the values of lactic acid and hydrogen ion $(\mathrm{H}+)$ to increase in the muscle. Metabolites that accumulate in the muscle put pressure on the muscle cell walls and provide expansion around the muscle.

\subsection{Working Mechanism of Blood Flow Restriction}

\subsubsection{Lactic Acid-Metabolite Mechanism}

BFR training works by increasing the production of muscle metabolite products or waste, such as lactic acid and hydrogen ions $(\mathrm{H}+)$. These metabolites are chemical irritants that stress muscle tissue and surrounding tissues to respond to changing adaptations (Novo, 2016).

\subsubsection{Cell Growth Mechanism}

There continues to be an increase in fluid within the working muscle as a direct result of venous blood flow restriction. As the muscles contract, they move the fluid away from them like a squeezed sponge. As the fluid decreases with the contraction of the muscle, it flows into the muscle as the contraction relaxes. As there is more fluid withdrawal and metabolite accumulation, muscle cells begin to grow (Novo, 2016).

\subsection{Application of Blood Flow Restriction}

To wrap the tourniquet around the limb to which blood flow restriction is to be applied, a point should be created by finding the larger trochanter with a bony protrusion on the lateral side of the femur in the lower extremity, just below the shoulder bone protrusion in the upper extremity. This marked place is the reference point during the repetitive application period.

\subsubsection{Upper and Lower Extremity Reference Points}

It is necessary to determine the radial pulse in the wrist for the upper extremity and the tibial pulse in the ankle for the lower extremity with blood flow restriction. Heart rate measurement will not occur if too much external pressure is applied.

\subsubsection{Upper and Lower Extremity Elastic Bandage}

The bandage should be wrapped completely around the limb with even pressure and the pulse should be checked. If there is no pulse, the bandage should be loosened until the pulse shows up. For the pressure level, the individual should be asked about his condition and make sure that he is within the 7-8 / 10 exercise zone.

\subsection{Materials Used in Blood Flow Restriction}

In the literature review, it is seen that many researchers generally use elastic bandage and pneumatic tourniquet systems. Loenneke et al. $(2013 ; 2014)$ put forward in their study that there is little difference when arterial occlusion or unsuccessful repeats are reached using cuffs of the same width on the lower body but made of two different materials. 
Buckner et al. (2017), on the other hand, report that there are unexpectedly large differences in cuff width in the resting AOP using different but similarly sized $(3 \mathrm{~cm}, 5$ $\mathrm{cm})$ cuffs on the upper body.

\subsubsection{Cuff Pressure}

It uses a 10-point numerical system for a safe training zone (Novo, 2016).

- 1-5 / 10: Tissue pressure is present, but venous occlusion is not seen at these levels.

- 7-8 / 10: It is the optimal exercise zone. At this pressure level, arterial blood flow is still occurring and venous blood flow is close to complete occlusion.

- 10/10: It is the complete closure of both arterial and venous blood flow. This training zone is dangerous. Signs and symptoms appearing in this area are the wrist radial pulse loss, numbness at points far from the center of the body, severe pain and whitening of the skin color. This level should be avoided.

\subsubsection{Air Pressure Scale}

Combines 10-point numerical system with approved pressure ranges. Air pressure varies between the upper and lower extremities. Approved intervals to create a safe training zone are indicated below.

- Upper Extremity Pressure: 100-220 mmHG

- Lower Extremity Pressure: 150-250 mmHG

Table 1: Equivalent of Air Pressure Scale in 10 Point Digital System

\begin{tabular}{|llc|}
\hline \multirow{2}{*}{$1-5 / 10:$} & Upper Extremity & $:<100$ \\
& Lower Extremity & $<150$ \\
\hline \multirow{2}{*}{$7-8 / 10:$} & Upper Extremity & $: 100-220$ \\
& Lower Extremity & $150-250$ \\
\hline \multirow{2}{*}{$10 / 10:$} & Upper Extremity & $:>220$ \\
& Lower Extremity & $:>250$ \\
\hline
\end{tabular}

\subsection{Resistance Training with Blood Flow Restriction}

In some studies, in the literature, resistance training with BFR has been observed to increase mTOR-related signaling proteins and muscle protein synthesis (Fujita et al., 2007; Fry et al., 2010). In a different study, Kubo et al. (2006) investigated the effects on specific tension and tendon properties comparing the low-intensity resistance training with BFR and high-intensity resistance training with BFR and showed that similar results were obtained in both training methods.

In studies on muscle hypertrophy, it is said that low-intensity exercise with BFR gets similar results to traditional strength training, and increases in muscle hypertrophy are observed on tests performed after exercise (Takarada et al., 2000b; Gürel, 2013). However, Dankel et al. (2016) could not find any significant difference in blood flow restriction to be applied after exercise is over, and suggest that more research should be done to determine whether there is an effect of blood flow restriction on muscle hypertrophy after exercise is over.

In two studies conducted at different intervals in the literature on muscle strength, the effects of vascular occlusion during low-intensity exercise were examined, and 
significant increases were found in the occlusion groups (Yokokawa et al., 2008; Brandner et al., 2019). In addition, Takarada et al. (2004) investigated the short and long-term effects of various combinations of vascular occlusion on isometric and isokinetic forces, and detected an increase in the group with BFR.

In studies conducted on performance athletes, the effects of exercises with BFR on strength increase and muscle formation were examined, and it was observed that strength development was achieved significantly when the groups with BFR were compared with the groups without restrictions (Takarada et al., 2002; Boyanmıs, 2018; Korkmaz, 2018). In a recent study, using different methods of blood flow restriction including high, medium and low intensity, a study was conducted on the evaluation of effects of squatting on the jump performance of the professional athletes. As the result of the study, it was determined that the high-intensity BFR technique was more effective on jumping performance than other groups (Türkdoğan, 2019).

In their study, Cook et al. (2017) obtained similar results by comparing them with traditional resistance training in order to examine the changes in the muscle crosssectional area and muscle volume of vascular occlusion in low-intensity exercise. In another study, it was found that the effects of low-intensity vascular occlusion on muscle volume were positive, and it supports the previous study (Jessee, 2018). In addition, it has been reported that exercises performed with BFR on individuals after the reconstruction of the anterior cruciate ligament have an effect on muscle strength, muscle volume and functions, and that individuals show improvements in functional parameters during the period after injury (Ohta et al., 2003; Demirci, 2019). In a recent study, the effects of exercising with the BFR technique on healthy individuals on their strength, joint position and functional motor performance were examined and significant improvements were observed after exercise (Arasan, 2019).

\subsection{Exercise Prescription}

It is thought that the exercise programs that will be designed for the implementation of resistance training with BFR will guide the practitioners.

Table 2: Blood Flow Restriction Training Program Planning Variables

\begin{tabular}{|ll|}
\hline Training Frequency & $: 2-3$ times a week \\
\hline Training Load & $: 1$ MT 20-40\% \\
\hline Type of Training & $:$ Small / Large Muscle Groups (Arm / Leg, Single / Double Sided) \\
\hline BFR Restriction Period & $: 5-10$ minutes per exercise \\
\hline BFR Restriction Form & $:$ Continuous / Intermittent \\
\hline Cuff Width & $: 5 \mathrm{~cm}$ (Small), 10/12 cm (Medium), 17/18 cm (Wide) \\
\hline Cuff Pressure & $: 100-250 \mathrm{mmHg}$ \\
\hline Number of Sets & $: 2-4$ \\
\hline Number of Repetitions & $: 75(30-15-15-15)$ \\
\hline Rest Between Sets & $: 30-60 \mathrm{sec}$ \\
\hline Application Speed & $: 1-2 \mathrm{sec}$ (Concentric and Eccentric) \\
\hline Practice & $:$ Until the Planned Repeat Program is Completed \\
\hline
\end{tabular}




\section{Conflict of Interest Statement}

The authors declare no conflicts of interests.

\section{About the Authors}

Ömür Gülfırat is a master of fitness trainer and good at gymnastics. He is employed as a lecturer of Physical Education and sports at University in İstanbul. His research interests include program fitness training, performance of sports, gymnastics.

Halil Bişgin is an assistant professor at University of Dumlupınar Kütahya, faculty of Physical Education and sports, Republic of Turkey. His research interests include program sports management, wrestling, gymnastics.

\section{References}

Arasan, D. D. (2019). Sağlıklı Bireylerde Kan Akışını Kısıtlayarak Yapılan Egzersizlerin Kuvvet, Eklem Pozisyon Duyusu ve Fonksiyonel Motor Performans Üzerine Etkisi. (Yayımlanmamış Doktora Tezi). Dokuz Eylül Üniversitesi/Sağlık Bilimleri Enstitüsü, İzmir.

Boyanmış, A. H. (2018). Taekwondocularda Pliometrik ve Kan Akımı Kısıtlama Antrenmanlarının Kuvvet Gelişimine Etkisi. (Yayımlanmamış Yüksek Lisans Tezi). Mersin Üniversitesi/Eğitim Bilimleri Enstitüsü, Mersin.

Brandner, C. R., Clarkson, M. J., Kidgell, D. J. and Warmington, S. A. (2019). Muscular Adaptations to Whole Body Blood Flow Restriction Training and Detraining. Frontiers in Physiology, 10:1099. doi:10.3389/fphys.2019.01099.

Buckner, S. L., Dankel, S. J., Counts, B. R., Jessee, M. B., Mouser, J. G., Mattocks, K. T., Laurentino, G. C., Abe, T. and Loenneke, J. P. (2017). Influence of Cuff Material on Blood Flow Restriction Stimulus in The Upper Body. The Journal of Physiological Sciences, 67, 207-215. doi:10.1007/s12576-016-0457-0.

Cook, S. B., LaRoche, D. P., Villa, M. R., Barile, H. and Manini, T. M. (2017). Blood Flow Restricted Resistance Training in Older Adults at Risk of Mobility Limitations. Experimental Gerontology, 99:138-145. doi:10.1016/j.exger.2017.10.004.

Dankel, S. J., Buckner, S. L., Jessee, M. B., Mattocks, K. T., Mouser, J. G., Counts, B. R., Laurentino, G. C., Abe, T. and Loenneke, J. P. (2016). Post-exercise Blood Flow Restriction Attenuates Muscle Hypertrophy. European Journal of Applied Physiology, doi:10.1007/s00421-016-3447-2.

Demirci, S. (2019). Ön Çapraz Bağ Rekonstrüksiyonu Sonrası Kan Akımı Kısıtlamalı Pliometrik Eğitimin Kas Kuvveti ve Fonksiyon Üzerine Etkisi. (Yayımlanmamış Doktora Tezi). Hacettepe Üniversitesi/Sağlık Bilimleri Enstitüsü, Ankara.

Fry, C. S., Glynn, E. L., Drummond, M. J., Timmerman, K. L., Fujita, S., Abe, T., Dhanani, S., Volpi, E. and Rasmussen, B. B. (2010). Blood Flow Restriction Exercise Stimulates mTORC1 Signaling and Muscle Protein Synthesis in Older Men. European Journal of Applied Physiology, 108(5), 1199-1209. 
Fujita, S., Abe, T., Drummond, M. J., Cadenas, J. G., Dreyer, H. C., Sato, Y., Volpi, E. and Rasmussen, B. B. (2007). Blood Flow Restriction During Low-Intensity Resistance Exercise Increases S6K1 Phosphorylation and Muscle Protein Synthesis. European Journal of Applied Physiology, 103:903-910. doi:10.1152/japplphysiol.00195.2007.

Gürel, G. (2013). Venöz Kan Akımı Kısıtlaması ile Uygulanan Ağırlık Antrenmanının Kas Hipertrofisi ve Kuvvetine Etkisinin Araştırılması. (Yayımlanmamış Doktora Tezi). Kocaeli Üniversitesi/Sağlık Bilimleri Enstitüsü, Kocaeli.

Hamilton, D. L., MacKenzie M. G. and Baar K. R. (2009). Molecular Mechanisms of Skeletal Muscle Hypertrophy Using Molecular Biology to Understand Muscle Growth. Muscle Plasticity - Advances in Biochemical and Physiological Research, 45-93 ISBN:978-81-308-0322-7.

Jessee, M. B., Buckner, S. L., Mouser, J. G., Mattocks, K. T., Dankel, S. J., Abe, T., Bell, Z. W., Bentley, J. P. and Loenneke, J. P. (2018). Muscle Adaptations to High-Load Training and Very Low-Load Training with and Without Blood Flow Restriction. Frontiers in Physiology, 9:1448. doi:10.3389/fphys.2018.01448.

Kenney, W. L., Wilmore, J. and Costill, D. (2015). Physiology of sport an exercise (6. Bask1). Champaign: Human Kinetics.

Korkmaz, E. (2018). 19 Yaş Altı Erkek Futbol Takımı Oyuncularında 6 Haftalık Kan Akışı Kisitlama Antrenmanının Kas Kuvveti ve Kasın Mimarisi Üzerine Etkisinin Ultrasonografik Olarak Değerlendirilmesi. (Yayımlanmamış Yüksek Lisans Tezi). Osmangazi Üniversitesi/Sağlık Bilimleri Enstitüsü, Eskişehir.

Kraemer, W. J., Adams, K., Cafarelli, E., Dudley, G. A., Dooly, C., Feigenbaum, M. S., Fleck, S. J., Franklin, B., Fry, A. C., Hoffman, J. R., Newton, R. U., Potteiger, J., Stone, M. H., Ratamess, N. A. and Triplett-McBride, T. (2002). American College of Sports Medicine Position Stand. Progression Models in Resistance Training for Healthy Adults. Medicine and Science in Sports and Exercise, 34(2), 364-380.

Kubo, K., Komuro, T., Ishiguro, N., Tsunoda, N., Sato, Y., Ishii, N., Kanehisa, H. and Fukunaga, T. (2006). Effects of Low-Load Resistance Training with Vascular Occlusion on The Mechanical Properties of Muscle and Tendon. Journal of Applied Biomechanics, 22(2), 112-119.

Larkin, K. A., Macneil, R. G., Dirain, M., Sandesara, B., Manini, T. M. and Buford, T. W. (2012). Blood Flow Restriction Enhances Post-Resistance Exercise Angiogenic Gene Expression. Medicine and Science in Sports and Exercise. 44, 2077-2083. doi:10.1249/MSS.0b013e3182625928.

Loenneke, J. P., Thiebaud, R. S., Fahs, C. A., Rossow, L. M., Abe, T. and Bemben, M. G. (2013). Effect of Cuff Type on Arterial Occlusion. Clinical Physiology and Functional. Imaging, 33, 325-327. doi:10.1111/cpf.12035.

Loenneke, J. P., Thiebaud, R. S., Fahs, C. A., Rossow, L. M., Abe, T. and Bemben, M. G. (2014). Blood Flow Restriction: Effects of Cuff Type on Fatigue and Perceptual Responses to Resistance Exercise. Acta Physiology Hungarica, 101, 158-166. doi:10.1556/APhysiol.101.2014.2.4.

Nakajima, T., Kurano, M., Iida, H., Takano, H., Oonuma, H., Morita, T., Meguro, K., Sato, Y., Nagata, T. and Kattsu Training Group (2006). Use and Safety of Kaatsu 
Training: Results of a National Survey. International Journal of Kaatsu Training Research, Volume 2:5-13.

Novo, M. G. (2016). Blood flow restriction training manual. Erişim: https://www.liftersclinic.com.

Ohta, H., Kurosawa, H., Ikeda, H., Iwase, Y., Satou, N. and Nakamura, S. (2003). LowLoad Resistance Muscular Training with Moderate Restriction of Blood Flow After Anterior Cruciate Ligament Reconstruction. Acta Orthopaedica Scandinavica, 74(1), 62-68.

Patterson, S. D., Hughes, L., Head, P., Warmington, S. and Brandner, C. R. (2017). Blood Flow Restriction Training: A Novel Approach to Augment Clinical Rehabilitation: How to Do It. British Journal of Sports Medicine, 51, 1648-1649. doi:10.1136/bjsports2017-097738.

Scott, B. R., Loenneke, J. P., Slattery, K. M. and Dascombe, B. J. (2015). Exercise with Blood Flow Restriction: An Updated Evidence-Based Approach for Enhanced Muscular Development. Sports Medicine, 45,313-325. doi:10.1007/s40279-014-0288-1.

Takarada, Y., Nakamura, Y., Aruga, S., Onda, T., Miyazaki, S. and Ishii, N. (2000a). Rapid Increase in Plasma Growth Hormone After Low-Intensity Resistance Exercise with Vascular Occlusion. Journal of Applied Physiology, 88(1):61-5.

Takarada, Y., Takazawa, H., Sato, Y., Takebayashi, S., Tanaka, Y. and Ishii, N. (2000b). Effects of Resistance Exercise Combined with Moderate Vascular Occlusion on Muscular Function in Humans. Journal of Applied Physiology, 88(6), 2097-2106.

Takarada, Y., Sato, Y. and Ishii, N. (2002). Effects of Resistance Exercise Combined with Vascular Occlusion on Muscle Function in Athletes. European Journal of Applied Physiology, 86(4), 308-314. doi:10.1007/s00421-001-0561-5.

Takarada, Y., Tsuruta, T. and Ishii, N. (2004). Cooperative Effects of Exercise and Occlusive Stimuli on Muscular Function in Low-Intensity Resistance Exercise with Moderate Vascular Occlusion. The Japanese Journal of Physiology, 54(6), 585-592.

Türkdoğan, H. E. (2019). Kan Akımını Kısıtlayıcı Yöntem ile Yapılan Skuat Hareketinin Sıçrama Performansı Üzerine Akut Etkisi. (Yayımlanmamış Yüksek Lisans Tezi). Pamukkale Üniversitesi/Sağlık Bilimleri Enstitüsü, Denizli.

Wernbom, M., Augustsson, J. and Thomee, R. (2006). Effects of Vascular Occlusion on Muscular Endurance in Dynamic Knee Extension Exercise at Different Submaximal Loads. Journal of Strength and Conditioning Research, 20(2), 372.

Yokokawa, Y., Hongo, M., Urayama, H., Nishimura, T. and Kai, I. (2008). Effects of LowIntensity Resistance Exercise with Vascular Occlusion on Physical Function in Healthy Elderly People. Bioscience Trends, 2(3), 117-123. 
Authors will retain the copyright of their published articles agreeing that a Creative Commons Attribution 4.0 International License (CC BY 4.0) terms will be applied to their work. Under the terms of this license, no permission is required from the author(s) or publisher for members of the community to copy, distribute, transmit or adapt the article content, providing a proper, prominent and unambiguous attribution to the authors in a manner that makes clear that the materials are being reused under permission of a Creative Commons License. Views, opinions and conclusions expressed in this research article are views, opinions and conclusions of the author(s). Open Access Publishing Group and European Journal of Physical Education and Sport Science shall not be responsible or answerable for any loss, damage or liability caused in relation to/arising out of conflict of interests, copyright violations and inappropriate or inaccurate use of any kind content related or integrated on the research work. All the published works are meeting the Open Access Publishing requirements and can be freely accessed, shared, modified, distributed and used in educational, commercial and non-commercial purposes under a Creative Commons attribution 4.0 International License (CC BY 4.0). 